\title{
A Holistic Approach for Achieving Impact through CSR
}

\author{
Suhas P. Wani, ${ }^{*}$ Girish Chander and Kaushal K. Garg \\ International Crops Research Institute for the Semi-Arid Tropics, \\ Patancheru, India
}

\begin{abstract}
Food and nutritional security of projected population of 9.7 billion globally and 1.7 billion in India by 2050 is the major challenge of the 21st century. Alongside the challenge is to improve farmers' income and upgrade agriculture as a business to make it attractive to the youth and generate livelihood options through value chain, as $55 \%$ of the population in India is dependent on agriculture and allied sectors. Holistic solutions are needed to effectively address the issues of increasing land degradation, water scarcity and threat of climate change to bring in sustainable system intensification and diversification to high-yielding, climate-smart and high-value crops. There is a need to focus on enhancing system productivity through crops and livestock and services in a holistic manner rather than crops alone. In spite of availability of game-changing technologies, the farms are far from realizing the productivity potential mainly due to ineffective delivery of knowledge and scientific solutions. This necessitates the need to strengthen the 'Science of Delivery' of holistic solutions to farmers. Capacity building of farmers involving traditional and modern tools like information and communication technology, collectivization as producer organization, on-farm mechanization and infrastructure development for handling, storage and transport is the key to develop/promote significant control measures in production and effective linkages with the markets. Post-production is a sector that needs to be developed for income supplements at farm level as well as agro-zonewise processing facilities to strengthen farming enterprise. Targeted generation of livelihood options in the process is important for inclusive development, including mainstreaming of women.
\end{abstract}

\subsection{Why a Holistic Approach?}

Securing food and nutritional security is a major challenge of the 21st century as the global human population is projected to increase from around 6.9 billion in 2010 to around 9.7 billion by 2050 (United Nations, 2016). In India, population is also rapidly growing and is expected to reach 1460 million by 2025 and 1700 million by 2050 in contrast to 1210 million in 2011 (FAOSTAT, 2017; Government of India, 2017).
Along with food security of the masses, another issue in the country is that nearly $55 \%$ of the population in India is dependent on agriculture and allied sectors for their livelihoods; agriculture, meanwhile, contributes only $15 \%$ to the nation's gross domestic product (Government of India, 2016). The issue is further compounded by degrading soil and water resources and impending climate change. Vulnerability of the rural poor to climate change is very high due to poverty, poor infrastructure and urban centric

\footnotetext{
* Corresponding author: s.wani@cgiar.org
} 
development of service and manufacturing sectors. Large yield gaps especially in dryland agriculture (Wani et al., 2003, 2011a), along with lack of holistic approach to target system-context productivity, value chains and market linkages add to the plight of smallholders in the country. There is evidence indicating that every $1 \%$ increase in agricultural yields translates to $0.6 \%$ to $1.2 \%$ decrease in the percentage of absolute poor (Thirtle et al., 2002). So, a holistic approach for inclusive development in rural areas is needed that brings in agroecology-wise strategies along with framework of implementation, monitoring and evaluation for the desired impacts. Corporate social responsibility (CSR) resources are needed urgently for inclusive and sustainable development through improving rural livelihoods by investments in sustainable management of natural resources.

Significant growth has been achieved in agriculture since the green revolution, but it has also brought uncertainty in terms of sustainability, while there is an unfinished agenda of improving productivity and income of farmers. For example, groundwater and surface water resources in India are exploited to irrigate about 44 and 21 million ha of agricultural lands respectively that together cover nearly $46 \%$ of total cultivable land (Wani et al., 2016a). The groundwater resources have been indiscriminately exploited with withdrawal of less than $25 \mathrm{~km}^{3}$ $\left(\mathrm{km}^{3}=1\right.$ billion cubic metre) in the 1960 s increasing to more than $250 \mathrm{~km}^{3}$ in 2008 (Shah et al., 2009), and now threaten future sustainability. Per capita water availability in the country has decreased from $5177 \mathrm{~m}^{3}$ in 1951 to $1625 \mathrm{~m}^{3}$ in 2011, with an associated decrease in per capita water availability of $1345 \mathrm{~m}^{3}$ in 2025 and $1140 \mathrm{~m}^{3}$ by 2050 (Wani et al., 2012b; FAOSTAT, 2017; Government of India, 2017). Even with irrigation expansion in India, still around $45 \%$ of the area by the year 2050 will continue to remain as rainfed (Amarasinghe et al., 2007), where water scarcity is a major limiting factor and there are hot spot regions of poverty and malnutrition with potential opportunities in unexploited twoto fourfold yield gaps (Wani et al., 2009). As regards the land resources, the cropping intensity has increased from about 1.17 in the late 1960s/ early 1970 s to 1.38 during 2011 and supported enhanced food production from 74 million tons during 1966-67 to 259 million tons during
2011-12 (Government of India, 2016). However, mismanagement has led to widespread land degradation such as nutrient mining and declining soil carbon levels, which is now a major hindrance in enhancing productivity levels. Due to prolonged nutrient mining, drylands are depleted not only in primary nutrients like nitrogen, phosphorus and potassium but also secondary and micronutrients like sulfur, zinc, iron and boron (Sahrawat et al., 2007, 2010; Wani et al., 2011b, 2015; Chander et al., 2013a,b,c, 2014a). There are other important costs in terms of ecosystem services along with stagnation of yields. Farm productivity and resource use efficiency in both irrigated and rainfed systems are declining over the years, due to inappropriate water and land management practices, water scarcity, land degradation, land fragmentation, lack of access to credit and markets, etc. (Wani et al., 2016a,b). Further, the projected climate-change scenario has increased the chances of water uncertainty and land degradation, leading to the vulnerability of food production in tropical countries like India. This necessitates the need for holistic solutions for resilience-building of production systems and livelihoods of smallholders.

\subsection{Existing Death Valley of Impact - The Main Challenge}

In spite of a large number of game-changing technologies, there are large yield gaps in farmers' fields mainly due to the lack of awareness and access to the technologies (Wani et al., 2017). During development of a technology, it rarely moves ahead of proof-of-concept/pilot stage to reach hundred thousands or millions of farmers' fields for a significant effect and this gap acts like a death valley of impact for any technology (Fig. 2.1). Multiple exogenous factors, lack of synergy among actors and deficiencies in technology delivery mechanisms account for this gap. For a positive impact, the technologies need to be customized in the local context and so researchers can no longer remain external actors, but need to engage in action research to develop appropriate solutions together with resource users (Hagmann et al., 2002). We need to go beyond the compartmental approach for a significant impact to emerge on the ground. 


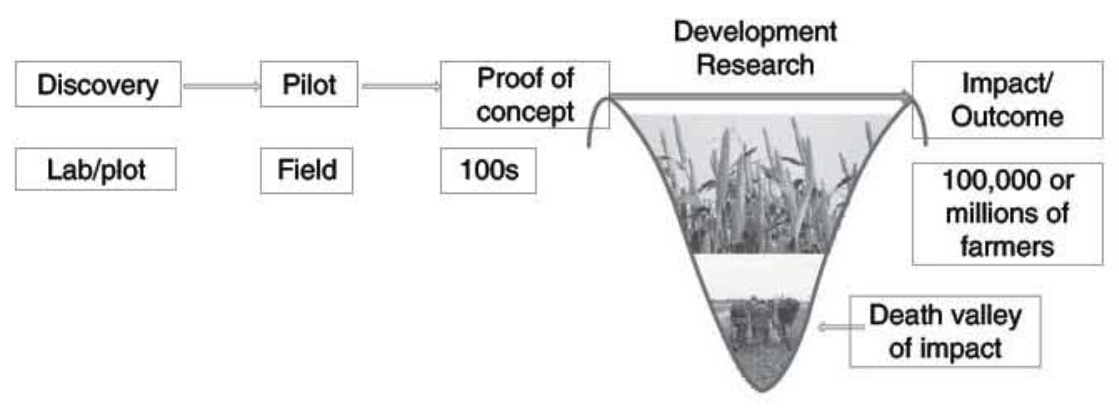

Fig. 2.1. Pictorial representation of the life cycle of a technology. From: Wani and Raju, 2016.

\subsection{Framework of Holistic Solutions \\ 2.3.1 Inclusive market-oriented development approach}

Inclusive market-oriented development (IMOD) represents the development pathway of the International Crops Research Institute for the Semi-Arid Tropics (ICRISAT) to help the poor to harness markets while managing risks in order to most effectively reduce poverty, hunger, malnutrition and environmental degradation across the dryland tropics (ICRISAT, 2010). It encompasses harnessing markets for the poor and managing risks (Fig. 2.2). Innovations are required that help the poor gain economies of scale, work collectively for greater market coordination and clout, achieve innovative financing, increase technology and information flow and application, among other challenges. Innovations must also be dynamic rather than static. They must enable and incentivize the poor to move from left to right along the development curve rather than the old model of static innovations that may solve narrow technical problems yet still leave them poor because they are divorced from a development strategy. Further, risks are especially high for smallholders because they have few resources to fall back on. Risk management requires external help through development assistance and safety nets. As incomes increase through IMOD, smallholders increasingly reinvest in building their capacities to withstand and rebound from shocks by increasing various forms of capital (social, human, financial, institutional, environmental and others) and become more and more resilient.

\subsubsection{Integrated watershed management - proven IMOD strategy for the drylands}

Pilot studies have indicated that a participatory integrated watershed management approach is one of the tested, sustainable and ecofriendly options to upgrade rainfed agriculture to meet growing food demand along with additional multiple benefits in terms of improving livelihoods, addressing equity issues and biodiversity concerns (Wani et al., 2012a,b, 2014). Water and soil conservation along with improved crop management opens up options for crop intensification and diversification, and strengthening the value chain for market-oriented development (Wani et al., 2012a). Comprehensive assessment of watershed programmes in India undertaken by ICRISAT-led consortium has also revealed that $99 \%$ of watershed projects were economically remunerative and were silently revolutionizing rainfed agriculture with a benefit-cost ratio of 2 , while reducing runoff by $45 \%$ and soil loss by $2-5$ tons/ha/year, increasing agricultural productivity by $50 \%$ to $400 \%$, and cropping intensity by $35 \%$ (Joshi et al., 2008; Wani et al., 2008). Additional benefits like generating rural employment of 151 days/ha/year were also noted. However, large scope existed for improving the performance of $68 \%$ of the watershed projects, which were performing below average. Programmes adopted uniform technologies, presuming that one size fits all. This resulted in good performance in only 700 to $1000 \mathrm{~mm}$ rainfall ecoregions, and the need for different strategies was indicated for low- and high-rainfall zones. There is also a need to consider climatic variability such as frequency of occurrence of 


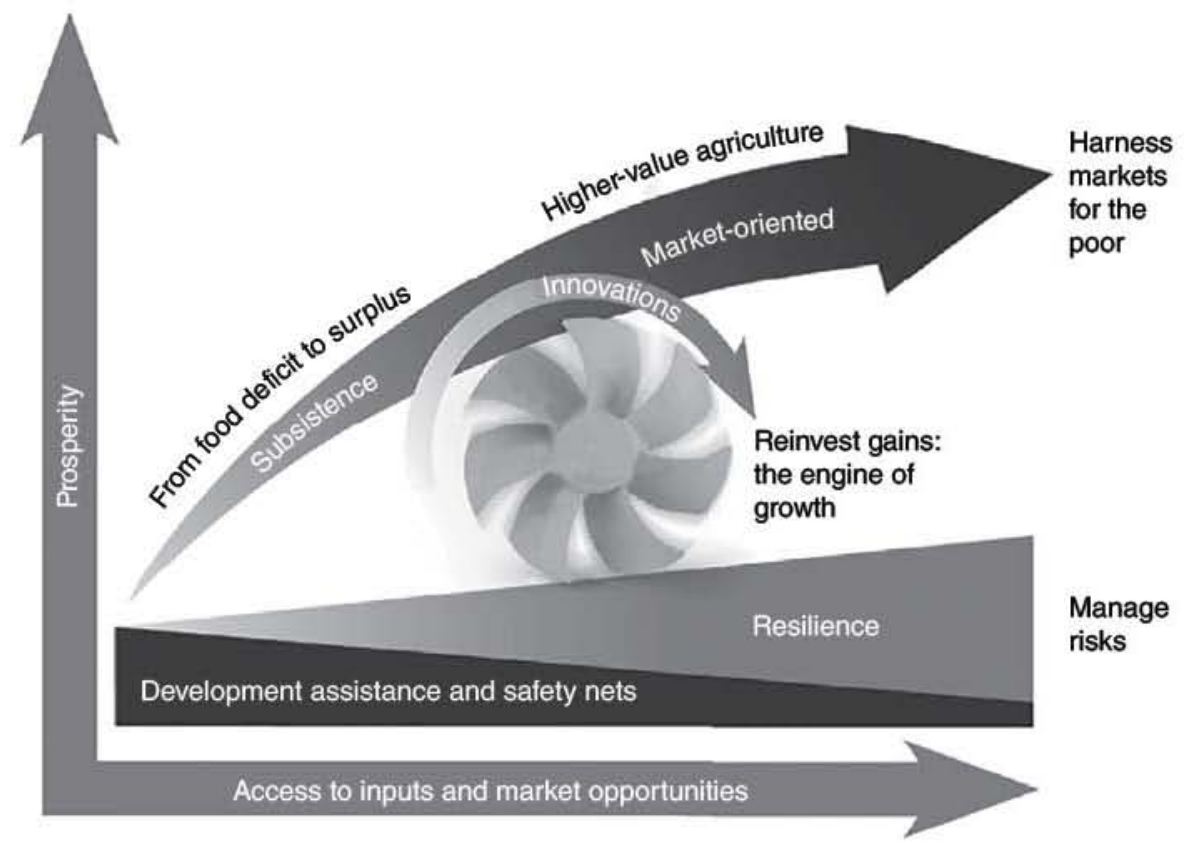

Fig. 2.2. Inclusive market oriented development pathway. From: ICRISAT, 2010.

extreme events while designing water-harvesting protocols. Experiences suggest that the implementation unit for watershed should be a microwatershed ( 5000 to $10,000 \mathrm{ha}$ ), which can be further integrated for planning purposes into meso- and macro-watersheds and subsequently to subbasin and basin levels.

\subsubsection{Strengthening the science of delivery of holistic solutions}

Despite a large network of research and development institutions, there are serious deficiencies in the delivery of knowledge and scientific solutions to the farmers. Private companies and dealer networks mainly cover this gap to provide information on inputs such as crop seeds and varieties, pesticides, fertilizers, etc., but in most cases may not be well informed and may be guided mostly by business interests. Timely access to quality inputs like seeds and micronutrients is a limiting factor. Infrastructure for precise and thorough diagnosis of soil health is poorly developed. In the vast network of laboratories established, most are half-functional or dysfunctional and cost-ineffective and rarely the laboratories are equipped for thorough analysis of macro and micronutrients and other chemical, physical and biological parameters. Further, farmers rarely get information in time and mostly in a format that they fail to understand. Climate change scenario (Kesava Rao and Wani, 2016) requires reorientation of management practices as effective adaptation and mitigation strategies. Different geographies are likely to experience changes in length of growing period, rainfall pattern, water scarcity, soil erosion, loss of soil carbon and nutrients, emergence of new pests and diseases, etc. A weak delivery system threatens not only our food security but also livelihoods of smallholders especially in the drylands.

In view of current and emerging challenges, there is a strong need for strengthening the 'Science of Delivery' to ensure benefits of science to farmers in the country. It encompasses collective action among knowledge-generating and knowledge-disseminating institutions in public and private sectors, enhancing access to timely knowledge and inputs along with necessary policy orientation. Bhoochetana, in Karnataka state of India, is an exemplary initiative of showcasing the 'Science of Delivery' of innovative 
technologies. The concept of ' $4 \mathrm{Cs}$ ' was adopted in the project (Wani, 2016). The first C is 'Consortium' of research, education and field-based agencies to implement this programme effectively at ground level. The second $\mathrm{C}$ is 'Convergence' within the department schemes and other programmes. The third C is 'Capacity building' of the consortium partners, farm facilitators, lead farmers and other stakeholders. The fourth $\mathrm{C}$ is ' $\mathrm{Col}-$ lective action' at all levels during programme implementation in a mission mode. Apart from adopting ' $4 \mathrm{Cs}$ ' concept, efforts were also made to ensure that the ' 4 Es' - efficiency, economic gain, equity and environment protection - were also achieved at ground level.

There is a strong need of rejuvenating extension system with innovations to keep pace with current challenges and aspirations of people. Information and communication technology (ICT) has an important role in scaling-up the sitespecific technologies. As an example in the Bhoochetana initiative in Karnataka, an App called Krishi Gyan Sagar was developed to provide up-to-date knowledge to the extension and para-extension workers in the local language as well as in English using tablets, smartphones and the web. This app had modules for plant protection and site-specific fertilizer recommendations, so proved quite effective in scaling-up the site-specific fertilizer recommendations. Farmer-to-farmer knowledge-sharing videos are another effective ICT tool. With a strong mobile phone network of nearly 500 million subscribers and the internet (>150 million internet users) spreading rapidly in rural India, these ICT-based tools can play a pivotal role in dissemination of real-time quality information and knowledge to farmers. Initiatives like Digital India and Soil Health Card schemes open up a serious opportunity for the use of ICT tools in agriculture. Investing in the 'Science of Delivery' of knowledge and timely access to inputs needed is the key to ensure food and nutritional security of the country.

\subsection{Holistic Solutions for Impact}

\subsubsection{Rainwater conservation}

Water is the major driver for food production. Efficient rainwater management especially in drylands is the key to alleviate severe water scarcity. In-situ water conservation (green water augmentation) is very important and contributes major share as globally green water used for food production is threefold more $\left(5000 \mathrm{~km}^{3} / \mathrm{year}\right)$ than blue (irrigated) water $\left(1800 \mathrm{~km}^{3} /\right.$ year $)$. In integrated watershed management, the first and topmost priority is in-situ moisture conservation by adopting appropriate landforms (contour cultivation, bunding including gated bunds, broadbed and furrow, ridge and furrow, tied ridges, dead furrows, etc.), soil organic matter amendments, mulching, canopy management and other practices.

Runoff rainwater is harvested in various ex-situ water harvesting structures at community and farm levels depending on the runoff and soil strata. Due focus needs to be given to rainwater harvesting at farm level as a drought proofing strategy in the drylands. Pilot studies in drylands of Andhra Pradesh and other sites indicate that small low-cost farm ponds provide access to water for critical irrigation during drought and check yield losses up to $20-60 \%$ (see Chapter 11, this volume; ICRISAT, 2015; Dryland Systems, 2016), and also facilitate other farm operations like growing vegetable gardens, composting, etc. Realizing the benefits, the concept is catching up with policy makers and donors. The Government of Andhra Pradesh has piloted the construction of about 600,000 farm ponds during 2016-17. Similarly, by 2016-17 in the state of Karnataka, storing runoff rainwater from the farmer's field and using stored water for crops has been promoted under the Krishi Bhagya scheme with over 100,000 farmers. The Jalyukt Shivar scheme in Maharashtra aims to make 5000 villages free of water scarcity every year through digging of farm ponds and other water conservation works. Understanding the farm-level focus, the Government of India scheme, Har Khet Ko Pani 'Pradhan Mantri Krishi Sinchayee Yojana (PMKSY)', has been formulated with the vision of extending the coverage of irrigation and improving water-use efficiency with end-to-end solutions on source creation, distribution and field application. Focused extensive efforts from all stakeholders including CSR partners are needed in this direction for droughtproofing of dryland farmers.

There is increasing evidence in the watershed sites that different interventions are effective in 
reducing rainwater runoff and the associated soil loss and improving groundwater recharge and other ecosystem services for human wellbeing (Joshi et al., 2005; Wani et al., 2011b, 2012a,b, 2014; Garg and Wani, 2013). In case of the Kothapally watershed pilot study in Telangana state, the soil loss in untreated area was $3.48 \mathrm{t} / \mathrm{ha}$, while in treated watershed it was 1.62 t/ha only. Similarly, in the ICRISAT on-station watershed, long-term mean data shows soil loss of $6.64 \mathrm{t} / \mathrm{ha}$ in untreated area and only $1.60 \mathrm{t} / \mathrm{ha}$ in treated area.

In the present scenario, there is also an urgent need to develop a policy framework to govern the use of groundwater resources. Aquifer mapping and recharging needs to be undertaken on a priority basis. Also, groundwater quality deterioration with increased heavy metals, pesticides and salinity is a point of concern. Such problem areas need urgent attention.

\subsubsection{Enhancing water-use efficiency}

Pilot studies have shown that various watershed interventions enhanced productive transpiration and increased rainwater use efficiency for crop production by $13-160 \%$ (Wani $e t$ al., 2012a). Enhancing the water-use efficiency and minimizing the unproductive evaporation loss of water through micro-irrigation (MI) systems (sprinklers and drip) is also a major opportunity in India (ICRISAT, 2016). Properly designed and managed MI systems can save up to $40-80 \%$ of water through increased water use efficiency up to $100 \%$ when compared to a mere $30-40 \%$ under the conventional surface irrigation system (Palanisami et al., 2011). In India, total potential area coverage under $\mathrm{MI}$ is about 42 million ha through groundwater resources (Wani et al., 2009; Palanisami et al., 2011). Of this, about 30 million ha area is suitable for sprinkler irrigation for crops like cereals, pulses and oilseeds in addition to fodder crops, and 12 million ha for drip irrigation for cotton, sugarcane, fruits and vegetables, spices, condiments and some pulse crops like pigeonpea, etc. The percentage of actual area against the potential area estimated under drip irrigation in different states ranges from negligible in Nagaland to as much as $50 \%$ in undivided Andhra Pradesh (presently Andhra Pradesh and Telangana state), followed by Maharashtra
(43\%) and Tamil Nadu with 24\% (Palanisami et al., 2011). In case of sprinkler irrigation, the percentage of actual area against the potential area estimated was as low as $0.01 \%$ (Bihar) and the highest was 52\% (Andhra Pradesh). Compared to the potential of 42 million ha in the country, area under MI during 2011 was only 3.87 million ha (1.42 million ha under drip and 2.44 million ha under sprinkler) which is about $9 \%$ of the entire potential, which shows huge scope to harness the full potential.

\subsubsection{Soil health}

In view of widespread multiple nutrient deficiencies in Indian soils and exemplary impact seen under the Bhoochetana initiative in Karnataka and pilot sites across India, soil health mappingbased fertilizer management is a proven lowhanging entry point intervention for improving productivity and livelihoods, while strengthening the basic soil resource base. Under the Bhoochet$a n a$, the strategies to rejuvenate farm soil health through balancing the deficient micro- and secondary nutrients along with primary nutrients have shown $20 \%$ to $70 \%$ higher food production (Wani, 2012; Wani et al., 2013; Chander et al., 2016; ICRISAT, 2016). Even in comparatively drier years, application of balanced nutrients through including micro- and secondary nutrients significantly increased grain yield and aboveground dry matter which provides resilience against drought and food security (Uppal et al., 2015). During 2009 to 2013, more than 5 million farmers benefited and net economic benefits through increased production were estimated as US\$353 million ( $₹ 1963$ crore). Taking the lead, the Government of Andhra Pradesh has also initiated the Rythu Kosam initiative with soil health rejuvenation as low-hanging technology to harness and build on it to improve primary-sector productivity and profitability along the value chain. Nutrient depletion also affects the quantity and quality of crop residue (Blümmel et al., 2009a,b; Haileslassie et al., 2011), which has an important role as feed components in the dominant mixed crop-livestock systems, and thereof affects the potential milk yield as high as $40 \%$ (Haileslassie et al., 2013). There is also evidence of relation of soil quality and balanced fertilization with food quality, especially in terms 
of micronutrient contents (Sahrawat et al., 2008, 2013: Chander et al., 2013b) with a great scope to have widespread impact in reducing malnutrition in women and children, which is an important global issue. Integrated management of soil health not only increases food and nutritional security but also renders ecosystem benefits through increasing carbon sequestration, nutrient nitrogen and phosphorus use efficiency and decreasing fertilizer-based pollution (Wani et al., 2003; Chander et al., 2014b), and thereby ensures sustainability.

As smallholders dominate Indian agriculture and considering the practical difficulties, soil health mapping can be effective when adopted as a national strategy (Wani et al., 2016b). Uniform sampling guidelines to collect samples in grids representing effectively the topography, soil texture, soil colour, farm size, cropping systems and management practices are important. In order to ensure quality, protocols and processes for accreditation of laboratories assume importance. The quality assurance standards as well as mechanisms to ensure quality analysis by the accredited labs by empowering leading institutions are important. Soil test-based fertilizer recommendations including deficient micro- and secondary nutrients should be developed at block (cluster of villages) level. Subsequently, villageand farmer-based recommendations should be made as awareness develops among the farmers, and the government is geared up to handle knowledge dissemination for villagers and individuals. Taking into account the benefits of integrated nutrient management, incentives are required to promote the use of organic manures as well as biofertilizers. There is an urgent need to look at policies and innovative institutional arrangements for ensuring quality supply of biofertilizers and organic manure to the farmers by recycling organic wastes generated both in urban and rural areas. As an example, crops like pigeonpea, cotton, maize, pearl millet and sorghum grown in around 37 million ha in India produce more than 100 million tons hardy straw biomass per year, which has little economic value or effective alternate use by farmers. This biomass is a potential opportunity to recycle plant nutrients worth more than ₹3000 crore per year through innovations in arranging shredders for chopping biomass on sharing basis and promoting accelerated vermicomposting technologies or aerobic composting which prove to be economically remunerative from the first year. Along with mapping for potential recyclable biomass, regions with current low chemical fertilizer use could also be prioritized and promoted as niche areas for organic farming without compromising with yield and harnessing premium price for the farmers. From sustainability point of view, land use planning based on land and agroecological capability is important and it can be promoted through incentivizing the farmers to adopt the recommended cropping system and applying penalties in terms of not providing the incentives and market support for crops that are not to be grown in a given agroecoregion.

\subsubsection{Crops and cropping systems management}

India has varying agroecologies from arid and semi-arid to subhumid and humid tropics with rainfall varying from $166 \mathrm{~mm}$ at Jaisalmer to $11,873 \mathrm{~mm}$ at Mawsynram, Meghalaya (Wani et al., 2016a). In addition, soil types range from sandy soils in the desert to clayey to peat soils. The huge potential of these varying agroecologies can be harnessed through science-led planning and development, which would ensure sustainability as well as profitability to farmers, and ensuring food and nutritional security to the country. However, such land-use planning could be promoted through incentivizing farmers to adopt recommended cropping system and adopting coherent policies. Further evidence is emerging that climate change is making the rainfall variability more intense with increased frequency of extreme events such as drought and floods. Shifts in agroclimates observed (Kesava Rao and Wani, 2016) may necessitate redelineation of agro-eco-zones for effectives plans.

Most of the crop production systems in the country are characterized by low-yielding varieties and varietal replacement of cereals, pulses and oilseeds is an important opportunity to enhance food security and improve farmers' incomes (Chander et al., 2016; Sawargaonkar et al., 2016). Studies have shown a productivity advantage of $30-140 \%$ through using improved high-yielding cultivars and 1 rupee spent on improved variety seed resulted in an additional return of ₹3-50 in crops like finger millet, sorghum, pearl millet, 
groundnut, soybean, castor, pigeonpea and chickpea (Chander et al., 2013c, 2016). Strengthening the seed systems along with decentralized on-farm seed production may be the key. Through addressing the issues of water and soil, policy support for market-led shift to high-value agriculture will empower smallholders economically, while enhancing food diversity (Chander et al., 2013a).

Cropping system management to meet shortfall of protein needs of human diets in India through enhancing pulses production is also a priority area. Pulses are considered very important sources of proteins, vitamins and minerals, and are popularly known as 'poor man's meat' and 'rich man's vegetable'. They contribute significantly to the nutritional security of the country. In a short term of 3-5 years, the country needs to be made self-sufficient by intensification of area under pulses ( $\sim 5$ million ha rice fallows and increasing cropping intensity through intercropping). Efforts need to be made on intensificationin pulsesareathroughincreasing productivity by scaling-up high-yielding cultivars, mechanization and efficient use of soil, water and nutrients, while simultaneously focusing on breeding lines to develop stress tolerant high-yielding cultivars to make pulses production systems climate resilient, profitable and sustainable to meet the growing demand in the country. Post-rainy fallow regions are potential opportunities for pulse revolution. Considerable amount of green water is available after the monsoon in these rice fallow systems, which could be easily utilized by introducing a short-duration legume crop with simple seed priming and micronutrient amendments (Kumar Rao et al., 2008; Wani et al., 2009; Singh et al., 2010). Of the 14.29 million ha ( $30 \%$ of rice-growing area) rice fallows available in the Indo-Gangetic Plains, spread across Bangladesh, Nepal, Pakistan and India, about 11.4 million ha ( $82 \%)$ are in the Indian states of Bihar, Madhya Pradesh, Chhattisgarh, Jharkhand, West Bengal, Odisha and Assam (Subba Rao et al., 2001). Taking advantage of the sufficiently available soil moisture, after harvesting rice crop, during the winter season in eastern India, growing early maturing chickpea with best-bet management practices provides opportunity for intensification (Harris et al., 1999; Kumar Rao et al., 2008). An economic analysis has shown that growing legumes in rice fallows is profitable for farmers with a benefit-cost ratio of more than 3 for many legumes. In addition, utilizing rice fallows for growing legumes could result in generating 584 million person-days employment for South Asia in addition to making India self-sufficient in pulses production.

Along with rice fallows, rainy season fallows are another opportunity for intensification and improving farm-based livelihoods. Vertisols and associated soils which occupy large areas are traditionally cultivated during the post-rainy season on stored soil moisture. Due to poor infiltration rates and waterlogging, farmers face difficulties in cultivating such lands during the rainy season. It is perceived that the practice of fallowing Vertisols and associated soils in Madhya Pradesh has decreased after the introduction of soybean. However, 2.02 million ha of cultivable land is still kept fallow in Central India, during kharif (rainy) season (Wani et al., 2002; Dwivedi et al., 2003). Vertisols with good moisture-holding capacity can be used to grow short-duration soybean by adopting reliable land management practices along with a good post-rainy season crop (Dwivedi et al., 2003; Wani et al., 2016c).

\subsubsection{Inclusive system-context development}

Inclusive system-context development signifies improving not only crop productivity but also the system productivity as such from agriculture, horticulture, animal husbandry and nonfarm sector to improve overall income of farmers. This concept focuses on identifying and developing resilient, diversified and more productive combinations of crop, livestock, rangeland, aquatic and agroforestry systems that increase productivity, reduce hunger and malnutrition, and improve the quality of life of the rural people. Customized innovative technological solutions are needed for enhancing system productivity. The major focus of CSR pilot site activities in general is on not only productivity enhancement and value chain in agriculture but also targeting horticulture plantations in marginal lands and fodder promotion for livestock among other site-specific interventions.

Inclusive development focuses on not only landholders but also the landless, including the mainstreaming of women through developing 
livelihood options along the value chain. Livelihood approach is the main pillar for integrated watershed management to improve family income as well as food and nutritional security.

\subsubsection{Modernizing agriculture: on-farm mechanization}

How to attract youth to agriculture and promote agribusiness? This is the most important issue in agriculture. Mechanization in modern agriculture is essential to do away with the drudgery and to improve operational efficiency of farms. On-farm mechanization is a scalable technology to improve productivity and income through efficiency in on-farm operations like sowing, interculture, harvesting and threshing. Studies indicate that increase in power availability results in an increase in crop intensity and productivity, envisaging the importance of mechanization in improving farm-based livelihoods. The scope of mechanization is demonstrated in pilot sites through various low-cost machinery on a sharing basis like the tropicultor for sowing operations on a raised landform, shredders for chopping biomass, easy planters for vegetable transplanting, seed grading machines, groundnut dry/wet pod threshers, etc.

\subsubsection{Value chain}

Agriculture is a disorganized industry with little control over production. Science and technology along with modern business management are needed to bring in such control features in this enterprise. Development of handling, storage and transport infrastructure is need of the day for effective handling of markets by the farmers. Post-production is an area which is mostly neglected and is in infancy. Primary processing at farm/village level along with zone-wise centralized processing facilities may contribute significantly in strengthening the farm sector. A favourable policy and collective effort by government, private sector, and research and development institutions are needed for the desired change. The terms of trade which are generally biased towards farming sector need to be reexamined and brought in line with other sectors.

\subsubsection{Collectivization: farmer producer organizations}

The small size and little bargaining power of farmers in the country is the major cause for most of the problems. Hence, collectivization of producers, especially small and marginal farmers, into farmer producer organizations (FPOs) has emerged as one of the most effective pathways to address the many challenges of agriculture like improved access to investments, technology, inputs and markets. The FPOs may enable reaping the benefits of economies of scale, reduce the transaction costs, improve profit margins and effectively manage risks and uncertainties. However, strong stewardship for capacity building and strengthening the knowledge base of farmers along with help in formulating good business plans and management will be needed for the success. The Government of Andhra Pradesh along with ICRISAT as technical partner is promoting FPOs under Rythu Kosam as a possible mechanism to intervene at farmer level to aggregate the produce and increase the collective incomes of the farming community in agriculture, horticulture, fisheries and dairy sectors.

\subsubsection{Capacity building and innovative extension system}

One of the reasons for large yield gaps between current yield and the potential yield that researchers achieve in a pilot site is the knowledge gap between 'What to do' and 'How to do it'. In spite of a number of new/improved technologies and products available at research institutes and state agricultural universities, farmers continue to do their business in a traditional manner. The reasons are multifarious as the current knowledge delivery system, i.e. extension system, is inefficient and does not benefit the farmers. As per a recent national sample survey, over $59 \%$ of the farm households received no assistance from either government or private extension services (NSSO, 2013). Therefore, there is an urgent need to reform the knowledge delivery systems in the states and the country by using innovative partnerships, tools, approaches and methods.

The CSR pilot and scaling-up experiences demonstrated that the information delivery 
mechanism can be strengthened by utilizing the services of practising farmers in the villages through farmers' field schools and farmer facilitators who stay in the villages for most of their time, unlike external experts who visit villages once in a while. The mix of tools like soil health cards, leaflets, wall writings, awareness campaigns, media, learning sites, farmer-to-farmer videos, pico projectors and ICT tools like mobile and internet facility have proved very effective in disseminating improved management options in the watersheds. With increasing connectivity through Digital India initiative of the Government of India, there is wide scope for decision making, monitoring, impact analysis and knowledge dissemination for resource optimization in agriculture and allied sectors using ICT. As trained human resource is a major constraint in the agricultural extension system, various ICTs are available which can bridge the gap between farmer and knowledge generator. Rapidly evolving information technology industry and a favourable environment for ICT in agriculture are giving a great boost to agricultural extension in India. Coordination among government and private companies is needed by developing or bringing them on to a common platform. Moreover, scientific tools such as GIS (geographical information system), remote sensing and systems modelling can be integrated and used effectively to benefit farmers. Better agro-advisory services for crop production, markets and other issues may benefit farmers a lot. Agromet Advisory Services can be successfully rendered if the forecasts can be interpreted properly for taking on-farm decisions and educating farmers continuously. Currently, agrometeorology advisory content is limited to SMS (short message service)-based system. In future, innovative tablet-based or emailbased agromet advisories along with detailed information as wall writings in local language need to be promoted. A consortium of partners comprising of India Metorological Department, national and state research organizations, state agricultural universities, international research organizations, government departments, nongovernmental organizations (NGOs) and commercial companies (related to seed, fertilizer and plant protection) is needed for ensuring a better advisory service and identifying suitable adaptation strategies. An alternate cropping plan, critical inputs such as seeds, fertilizers, pesticides, manures and postharvest strategies such as godowns, cold storage and marketing information should be made available through information centres at the state and district levels with a 24/7 toll-free number to avail of the services.

The CSR pilot and scaling-up experiences proved that enhancing partnerships and institutional innovations through the consortium approach is the major impetus for harnessing the potential of community watershed management to reduce poverty and environmental degradation. The underlying element of the consortium approach is to engage a range of actors to harness their strengths and synergies with the local community as the primary implementing unit. Through the consortium approach, complex issues can be effectively addressed by the joint efforts of key partners like national agricultural research system, NGOs, government organizations, international institutions, agricultural universities, community-based organizations and other private-interest groups, with farm households as the key decision makers. Thus, the consortium approach brings together the expertise of different areas to expand the effectiveness of the various watershed initiatives and interventions. The public-private partnership (PPP) is an effective strategy to minimize transaction costs and to coordinate and enforce relations between the partners engaged in production of goods and services.

Working on 'seeing is believing', pilot sites of learning need to be developed in each district as exemplary sites for training as well as developmental purposes and CSR pilot sites are serving well. Such sites of learning need to be developed by the scientific institutions by adopting the consortium approach and building PPP. These sites of learning would also provide field laboratories for undertaking strategic research in the area of management strategies as well as impact assessment, monitoring and evaluation studies.

\subsection{Summary and Key Findings}

Ensuring food and nutritional security of the burgeoning population in India is a big challenge for the country. From the food point of view and mainstreaming of smallholders, the focus on drylands, which were bypassed during the green revolution, is now inevitable. There 
are large and economically exploitable yield gaps in the drylands, which can be easily bridged with current levels of technologies if holistic and integrated soil-crop-water-livestock-related solutions adapted to local conditions are made available to farmers. The 'Science of Delivery', involving timely end-to-end collective action along the value chain is the way forwards. There is an urgent need to transform rainfed agriculture, not only for increasing agricultural production and profits, but also to make it attractive for youth and women as a respectable profession by using scientific tools for mechanization, knowledge sharing, establishing market linkages and value addition. Such practices ensure a larger share of benefits through retaining processing in the villages with substantially increased investments, enabling policies and institutions. Projects such as Bhoochetana in Karnataka and Rythu Kosam in Andhra Pradesh are examples of scaling-up initiatives and harnessing benefits for the farmers. At the country level, such initiatives need to be scaled-up through innovative technology-driven institutionalmechanisms with decentralized accountability for achieving large-scale impacts.

\section{References}

Amarasinghe, U.A., Shah, T., Turral, H. and Anand, B.K. (2007) India's Water Future to 2025-2050: Business-as-Usual Scenario and Deviations. IWMI Research Report 123. International Water Management Institute, Colombo, Sri Lanka.

Blümmel, M., Anandan, S. and Prasad, C.S. (2009a) Potential and limitations of by-product based feeding systems to mitigate greenhouse gases for improved livestock productivity. In: Gowda, N.K.S., Senani, S., Bhatta, R. and Pal, D.T. (eds) Diversification of Animal Nutrition Research in the Changing Scenario. Volume 1 (Lead papers). 13th Biennial Animal Nutrition Conference, 7-19 December 2009, Bangalore, India. ILRI, Hyderabad, India and Animal Nutrition Society of India, Bangalore, India, pp. 68-74.

Blümmel, M., Samad, M., Singh, O.P. and Amede, T. (2009b) Opportunities and limitations of food-feed crops for livestock feeding and implications for livestock-water productivity. Rangeland Journal 31, 207-213.

Chander, G., Wani, S.P., Maheshwer, D.L., Hemalatha, P., Sahrawat, K.L. et al. (2013a) Managing soil fertility constraints in market-led shift to high value agriculture for benefiting smallholders in the semi-arid tropics. Journal of SAT Agricultural Research 11, 1-11.

Chander, G., Wani, S.P., Sahrawat, K.L., Kamdi, P.J., Pal, C.K. et al. (2013b) Balanced and integrated nutrient management for enhanced and economic food production: case study from rainfed semi-arid tropics in India. Archives of Agronomy and Soil Science 59(12), 1643-1658.

Chander, G., Wani, S.P., Sahrawat, K.L., Pal, C.K. and Mathur, T.P. (2013c) Integrated plant genetic and balanced nutrient management enhances crop and water productivity of rainfed production systems in Rajasthan, India. Communications in Soil Science and Plant Analysis 44, 3456-3464.

Chander, G., Wani, S.P., Sahrawat, K.L., Dixit, S., Venkateswarlu, B. et al. (2014a) Soil test-based nutrient balancing improved crop productivity and rural livelihoods: case study from rainfed semi-arid tropics in Andhra Pradesh, India. Archives of Agronomy and Soil Science 60(8), 1051-1066.

Chander, G., Wani, S.P., Sahrawat, K.L. and Rajesh, C. (2014b) Enhanced nutrient and rainwater use efficiency in maize and soybean with secondary and micro nutrient amendments in the rainfed semi-arid tropics. Archives of Agronomy and Soil Science 61(3), 285-298.

Chander, G., Wani, S.P., Krishnappa, K., Sahrawat, K.L., Pardhasaradhi, G. and Jangawad, L.S. (2016) Soil mapping and variety based entry-point interventions for strengthening agriculture-based livelihoods exemplar case of 'Bhoochetana' in India. Current Science 110(9), 1683-1691.

Dryland Systems (2016) Small ponds make for big progress among farmers in India. Available at: http:// drylandsystems.cgiar.org/outcome-stories/small-ponds-make-big-progress-among-farmers-india (accessed 9 April 2018).

Dwivedi, R.S., Ramana, K.V., Wani, S.P. and Pathak, P. (2003) Use of satellite data for watershed management and impact assessment. In: Wani, S.P., Maglinao, A.R., Ramakrishna, A. and Rego, T.J. (eds) Integrated Watershed Management for Land and Water Conservation and Sustainable Agricultural Production in Asia. Proceedings of the ADB-ICRISAT-IWMI Project Review and Planning Meeting, 10-14 December 2001, Hanoi, Vietnam. International Crops Research Institute for the Semi-Arid Tropics, Patancheru, India, pp. 149-157. 
FAOSTAT (2017) Data: Annual Population. Available at: http://faostat.fao.org/site/550/default.aspx\#ancor (accessed 9 April 2018).

Garg, K.K. and Wani, S.P. (2013) Opportunities to build groundwater resilience in the semi-arid tropics. Ground Water 51(5), 679-691.

Government of India (2016) Agricultural Statistics at a Glance 2016. Directorate of Economics and Statistics, Department of Agriculture \& Cooperation, Ministry of Agriculture, Government of India, New Delhi. Available at: http://eands.dacnet.nic.in/PDF/Glance-2016.pdf (accessed 9 April 2018).

Government of India (2017) 2011 Census Data. Office of the Registrar General \& Census Commissioner, Ministry of Home Affairs Gol, New Delhi. Available at: http://censusindia.gov.in (accessed 9 April 2018).

Hagmann, J., Chuma, E., Muriwira, K., Connolly, M. and Ficarelli, P. (2002) Success factors in integrated natural resource management R\&D: lessons from practice. Conservation Ecology 5(2), 29.

Haileslassie, A., Blümmel, M., Clement, F., Descheemaeker, K., Amede, T. et al. (2011) Assessment of livestock feed and water nexus across mixed crop livestock system's intensification gradient: an example from the Indo-Ganaga Basin. Experimental Agriculture 47, 113-132.

Haileslassie, A., Blümmel, M., Wani, S.P., Sahrawat, K.L., Pardhasaradhi, G. and Samireddypalle, A. (2013) Extractable soil nutrient effects on feed quality traits of crop residues in the semiarid rainfed mixed crop-livestock farming systems of Southern India. Environment Development and Sustainability 15, 723-741.

Harris, D., Joshi, A., Khan, P.A., Gothkar, P. and Sodhi, P.S. (1999) On-farm seed priming in semi-arid agriculture: development and evaluation in maize, rice and chickpea in India using participatory methods. Experimental Agriculture 35, 15-29.

ICRISAT (2010) ICRISAT Strategic Plan to 2020 - Inclusive Market Oriented Development for Smallholder Farmers in the Tropical Drylands. International Crops Research Institute for the Semi-Arid Tropics, Patancheru, India. Available at: http://www.icrisat.org/who-we-are/sp/icrisat-sp-2020.pdf (accessed 9 April 2018).

ICRISAT (2015) Drylands get greener with low-cost agri interventions and shared resources in Andhra Pradesh, India. International Crops Research Institute for the Semi-Arid Tropics. Available at: http:// www.icrisat.org/newsroom/latest-news/happenings/happenings1699.htm (accessed 9 April 2018).

ICRISAT (2016) Annual Report 2015-16: Strengthening Bhoochetana: A Sustainable Agriculture Mission for Improved Livelihoods in Karnataka, Annual Report 2015-2016. International Crops Research Institute for the Semi-Arid Tropics. Available at: http://oar.icrisat.org/9919 (accessed 26 April 2018).

Joshi, P.K., Jha, A.K., Wani, S.P., Joshi, L. and Shiyani, R.L. (2005) Meta-analysis to Assess Impact of Watershed Programme and People's Participation. Research Report No. 8. International Crops Research Institute for the Semi-Arid Tropics, Patancheru, India/Asian Development Bank, Manila, Philippines.

Joshi, P.K., Jha, A.K., Wani, S.P., Sreedevi, T.K. and Shaheen, F.A. (2008) Impact of Watershed Program and Conditions for Success: A Meta-Analysis Approach. Global Theme on Agroecosystems, Report No. 46. International Crops Research Institute for the Semi-Arid Tropics, Patancheru, India/National Centre for Agricultural Economics and Policy Research, New Delhi.

Kesava Rao, A.V.R. and Wani, S.P. (2016) Impact of climate change on agriculture and food security. In: Juwvadi, Devi Prasad (ed.) Capacity Building for Climate Smart Agriculture. BS Publications, Hyderabad, India, pp. 27-52.

Kumar Rao, J.V.D.K., Harris, D., Kankal, M. and Gupta, B. (2008) Extending rabi cropping in rice fallows of eastern India. In: Riches, C.R., Harris, D., Johnson, D.E. and Hardy, B. (eds) Improving Agricultural Productivity in Rice-based Systems of the High Barind Tract of Bangladesh. International Rice Research Institute, Los Banos, Philippines, pp. 193-200.

National Sample Survey Organisation (NSSO) (2013) Situation Assessment Survey of Agricultural Households in India (70th round: July 2012-June 2013). Ministry of Statistics and Programme Implementation, New Delhi.

Palanisami, K., Mohan, K., Kakumanu, K.R. and Raman, S. (2011) Spread and economics of micro-irrigation in India: evidence from nine states. Economic \& Political Weekly XLVI (26 \& 27), 81-86.

Sahrawat, K.L., Wani, S.P., Rego, T.J., Pardhasaradhi, G. and Murthy, K.V.S. (2007) Widespread deficiencies of sulphur, boron and zinc in dryland soils of the Indian semi-arid tropics. Current Science 93 , 1428-1432.

Sahrawat, K.L., Rego, T.J., Wani, S.P. and Pardhasaradhi, G. (2008) Sulfur, boron, and zinc fertilization effects on grain and straw quality of maize and sorghum grown in semi-arid tropical region of India. Journal of Plant Nutrition 31(9), 1578-1584. 
Sahrawat, K.L., Wani, S.P., Pardhasaradhi, G. and Murthy, K.V.S. (2010) Diagnosis of secondary and micronutrient deficiencies and their management in rainfed agroecosystems: case study from Indian semiarid tropics. Communications in Soil Science and Plant Analysis 41(3), 346-360.

Sahrawat, K.L., Wani, S.P. and Pardhasaradhi, G. (2013) Balanced nutrient management: effects on plant zinc. Journal of SAT Agricultural Research 11, 1-3.

Sawargaonkar, G., Rao, S.R. and Wani, S.P. (2016) An integrated approach for productivity enhancement. In: Raju, K.V. and Wani, S.P. (eds) Harnessing Dividends from Drylands: Innovative Scaling up with Soil Nutrients. CAB International, Wallingford, Oxfordshire, pp. 201-235.

Shah, A., Wani, S.P. and Sreedevi, T.K. (2009) Impact of Watershed Management on Women and Vulnerable Groups. Proceedings of the Workshop on Comprehensive Assessment of Watershed Programs in India, 25 July 2007. International Crops Research Institute for the Semi-Arid Tropics, Patancheru, India.

Singh, P., Pathak, P., Wani, S.P. and Sahrawat, K.L. (2010) Integrated watershed management for increasing productivity and water use efficiency in semi-arid tropical India. In: Kang, Manjit S. (ed.) Water and Agricultural Sustainability Strategies. CRC Press, Boca Raton, FL, pp. 181-205.

Subba Rao, G.V., Kumar Rao, J.V.D.K. and Kumar, J. (2001) Spatial Distribution and Quantification of Rice-fallows in South Asia - Potential for Legumes. International Crops Research Institute for the Semi-Arid Tropics, Patancheru, India.

Thirtle, C., Beyers, L., Lin, L., McKenzie-Hill, V., Irz, X., Wiggins, S. and Piesse, J. (2002) The Impacts of Changes in Agricultural Productivity on the Incidence of Poverty in Developing Countries. DFID Report No. 7946. Department for International Development, London.

United Nations (2016) World Population Prospects, the 2015 Revision. UN Department of Economic and Social Affairs, Population Division, New York.

Uppal, R.K., Wani, S.P., Garg, K.K. and Alagarswamy, G. (2015) Balanced nutrition increases yield of pearl millet under drought. Field Crops Research 177, 86-97.

Wani, S.P. (2012) Bhoochetana - Rejuvenating Land and Livelihoods in Karnataka. International Crops Research Institute for the Semi-Arid Tropics, Patancheru, India.

Wani, S.P. (2016) Evolution of Bhoochetana. In: Raju, K.V. and Wani, S.P. (eds) Harnessing Dividends from Drylands: Innovative Scaling up with Soil Nutrients. CAB International, Wallingford, Oxfordshire, pp. 34-58.

Wani, S.P. and Raju, K.V. (2016) Lessons learnt and a way forward. In: Raju, K.V. and Wani, S.P. (eds) Harnessing Dividends from Drylands: Innovative Scaling up with Soil Nutrients. CAB International, Wallingford, Oxfordshire, pp. 290-305.

Wani, S.P., Pathak, P., Tam, H.M., Ramakrishna, A., Singh, P. and Sreedevi, T.K. (2002) Integrated watershed management for minimizing land degradation and sustaining productivity in Asia. In: Adeel, Z. (ed.) Integrated Land Management in the Dry Areas. Proceedings of a Joint UNU-CAS International Workshop, 8-13 September 2001, Beijing, China. United Nations University, Tokyo, Japan, pp. 207-230.

Wani, S.P., Pathak, P., Sreedevi, T., Singh, H. and Singh, P. (2003) Efficient management of rainwater for increased crop productivity and groundwater recharge in Asia. In: Kijne, J.W., Barker, R. and Molden, D. (eds) Water Productivity in Agriculture: Limits and Opportunities for Improvement. CAB International, Wallingford, Oxfordshire, pp. 199-215.

Wani, S.P., Sreedevi, T.K., Reddy, T.S.V., Venkateswarlu, B. and Prasad, C.S. (2008) Community watersheds for improved livelihoods through consortium approach in drought prone rainfed areas. Journal of Hydrological Research and Development 23, 55-77.

Wani, S.P., Sreedevi, T.K., Rockström, J. and Ramakrishna, Y.S. (2009) Rainfed agriculture - past trends and future prospects. In: Wani, S.P., Rockström, J. and Oweis, T. (eds) Rainfed Agriculture: Unlocking the Potential. Comprehensive Assessment of Water Management in Agriculture Series. CAB International, Wallingford, Oxfordshire, pp. 1-35.

Wani, S.P., Rockström, J., Venkateswarlu, B. and Singh, A.K. (2011a) New paradigm to unlock the potential of rainfed agriculture in the semi-arid tropics. In: Lal, R. and Stewart, B.A. (eds) World Soil Resources and Food Security. Advances in Soil Science. CRC Press, Boca Raton, FL, pp. 419-469.

Wani, S.P., Sahrawat, K.L., Sarvesh, K.V., Baburao Mudbi and Krishnappa, K. (2011b) Soil Fertility Atlas for Karnataka, India. International Crops Research Institute for the Semi-Arid Tropics, Patancheru, India.

Wani, S.P., Dixin, Y., Li, Z., Dar, W.D. and Chander, G. (2012a) Enhancing agricultural productivity and rural incomes through sustainable use of natural resources in the SAT. Journal of the Science of Food and Agriculture 92, 1054-1063.

Wani, S.P., Garg, K.K., Singh, A.K. and Rockström, J. (2012b) Sustainable management of scarce water resource in tropical rainfed agriculture. In: Lal, R. and Stewart, B.A. (eds) Soil Water and Agronomic Productivity. Advances in Soil Science. CRC Press, Boca Raton, FL, pp. 347-408. 
Wani, S.P., Sarvesh, K.V., Sahrawat, K.L., Krishnappa, K., Dharmarajan, B.K., Raju, K.V., Kaushik Mukherjee and Dar, W.D. (2013) Bhoochetana: Building Resilience and Livelihoods through Integrated Watershed Management. Resilient Dryland Systems Report No. 62. International Crops Research Institute for the Semi-Arid Tropics, Patancheru, India.

Wani, S.P., Chander, G. and Sahrawat, K.L. (2014) Science-led interventions in integrated watersheds to improve smallholders' livelihoods. NJAS - Wageningen Journal of Life Sciences 70/71, 71-77.

Wani, S.P., Chander, G., Sahrawat, K.L. and Pardhasaradhi, G. (2015) Soil test-based balanced nutrient management for sustainable intensification and food security: case from Indian semi-arid tropics. Communications in Soil Science and Plant Analysis 46(S1), 20-33.

Wani, S.P., Anantha, K.H., Garg, K.K., Joshi, P.K., Sohani, G. et al. (2016a) Pradhan Mantri Krishi Sinchai Yojana: Enhancing the Impact through Demand Driven Innovations. Research Report IDC-7. International Crops Research Institute for the Semi-Arid Tropics, Patancheru, India.

Wani, S.P., Chander, G., Bhattacharyya, T. and Patil, M. (2016b) Soil Health Mapping and Direct Benefit Transfer of Fertilizer Subsidy. Research Report IDC-6. International Crops Research Institute for the Semi-Arid Tropics, Patancheru, India.

Wani, S.P., Chander, G., Sahrawat, K.L., Pal, D.K., Pathak, P. et al. (2016c) Sustainable use of natural resources for crop intensification and better livelihoods in the rainfed semi-arid tropics of Central India. NJAS - Wageningen Journal of Life Sciences 78, 13-19.

Wani, S.P., Chander, G. and Anantha, K.H. (2017) Enhancing resource use efficiency through soil management for improving livelihoods. In: Rakshit, A., Abhilash, P., Singh, H. and Ghosh, S. (eds) Adaptive Soil Management: From Theory to Practices. Springer, Singapore, pp. 413-451. 